\title{
Klimatruslen - set fra et dansk perspektiv
}

\section{Af Jesper Theilgaard}

"Det danske vejr er Gajol-vejr"!

Sådan lød et slogan fra en slikfabrikant, og den helt ufarlige undertone i sloganet er et meget godt billede på vores historiske opfattelse af, at vejret i Danmark generelt er ufarligt. Vejret kan være irriterende, og man får ikke altid det, man ønsker eller har behov for, men grundlæggende ser vi ingen fare i vejrliget.

Til gengæld er vi særdeles interesserede i, hvordan vejret arter sig i udlandet, hvor der er større kræfter på spil. Udsendelser og nyheder om vejret har altid haft store seertal, og når katastroferne indtræder, følger vi med fra sofaen i god afstand til begivenhederne.

Spørgsmålet er så, om det ufarlige og nærmest jomfruelige er ved at forsvinde mellem hænderne på os, i takt med at temperaturen stiger. For $i$ disse år er det blevet mere synligt, at vejret ikke er, hvad det var engang. Vores hukommelse er ganske vist ikke den bedste ledesnor til at huske forandringerne, for hukommelsen er selektiv. Vi husker, det vi gerne vil huske. 'Vintrene var altid hvide og kolde, og somrene havde altid varme og solrige perioder'. Men var det nu også sådan? Nej, vi romantiserer ofte i vores hukommelse, så derfor må vi ty til faste data og optegnelser.

Her fremgår det, at temperaturen i Danmark er steget omkring 1,5 grader siden 1874 , hvor vi begyndte at måle vejrets elementer, og i samme periode har vi fået lagt ca. $100 \mathrm{~mm}$ til i den årlige nedbør.

Men mere interessant er det, at de største stigninger i både temperatur og nedbør er sket efter 1970'erne, hvor også den globale temperatur er steget en del - ikke som en jævn stigning, for det veksler meget fra år til år, men tendensen er tydelig, når vi ser det over en længere årrække.

Med den konstatering, at vejret og dermed klimaet er under forandring, kan vi så se på de trusler, forandringerne indebærer. Der er direkte trusler $i$ et forandret vejrlig, og der er de mere indirekte trusler fra de påvirkninger, det nye vejr vil give os.

Jesper Theilgaard er meteorolog og tidligere vejrvært ved DR. Han driver nu firmaet klimaformidling. 


\section{Mulighed eller trussel?}

Der er også positive elementer i en stigende temperatur. Hvis vi lige først dvæler lidt ved dem, så vil de højere temperaturer generelt give en længere vækstsæson, og da der er vand nok, burde det give sig udslag i større landbrugsudbytter. Måske kan nogle marker endda dyrkes to gange om året. De milde vintre kræver mindre opvarmning, og samtidig kan der være en forventning om, at glatføreuheld bliver sjældnere. Her er der dog den risiko, at hvis temperaturen svinger omkring frysepunktet, vænner vi os ikke til det

\section{Året 2018 blev et år, hvor der især på den nordlige halvkugle blev sat fokus på klimaet på grund af flere vejrhændelser, der havde stor mediebevågenhed.}

glatte føre, hvilket trækker i den anden retning. Endelig må det forventes, at antallet af kuldedødsfald mindskes.

Det er dog nok de mere negative konsekvenser, som er i fokus og i særdeleshed også her, vi skal sætte ind, hvor det er muligt. Endvidere er det ikke isoleret til Danmark, men i langt højere grad vil forandringerne spille ind $\mathrm{i}$ et globalt billede, hvor landene indbyrdes bliver påvirket af forandringerne.

Året 2018 blev et år, hvor der især på den nordlige halvkugle blev sat fokus på klimaet på grund af flere vejrhændelser, der havde stor mediebevågenhed.

Man skal dog altid huske, at det videnskabeligt er svært at tage enkelthændelser og bevise, at de opstod på grund af klimaændringerne. Det er derimod mere fornuftigt at se på, om hændelser bliver mere sandsynlige, og om de eventuelt vil blive forstærket af opvarmningen.

Et godt eksempel herpå er sommeren i Europa i 2018. Den lange varme og tørre sommer fik klimaet på alles læber, og spørgsmålene stod i kø, for var det klimaet, der nu direkte viste sit sande ansigt. Men vi har jo set tørke før, og somrene har da ind i mellem været varme og solrige - og så var 2017 jo helt modsat med meget regnfuldt og køligt vejr.

Men når man skal se på klimaets indflydelse på en hændelse - og sommeren i Europa kan ses som en hændelse - så ser forskerne på, om risikoen for, om den samme hændelse kan forekomme, er øget i et varmere klima. Her viste det sig så, at specifikke hedebølger i det centrale Europa vil forekomme dobbelt så ofte i vores varmere klima sammenlignet med et normalt klima. Hedebølger er teknisk set en periode på mindst tre dage i træk, hvor den højeste temperatur når 28 grader eller mere. Hedebølgen kan så være meget lokal eller dække et større område. Så muligheden for, at en hedebølge i Europa forekommer, er altså blevet forøget på grund af opvarmningen.

Her ser vi dermed en effekt af temperaturstigningen. Det er måske ikke overraskende, at en højere temperatur medfører større risiko for en hedebølge, men selv om det virker indlysende, skal der helst være et videnskabeligt grundlag at basere vurderingen på.

Det vil så være helt rimeligt at stille spørgsmålet, om der er en sammen- 
De menneskelige tragedier, der udspilledes i både Athen og i Californien, var store, og det der fortsætter, eller om det er væsentligt at forsøge at minimere de risici, brandene udgør for mennesker.

blot var tilfældigheder. Skul-

le vi i årene, der kommer, se tilsvarende forhold med den samme vejrtype i lang tid, så hæng mellem de to år 2017 og 2018, der unægtelig havde hver deres vejrtype. Fællesnævneren er i al fald, at vi havde den samme vejrtype gennem usædvanlig lang tid. Normalt skifter vejret hos os og i Nordeuropa generelt meget ofte. Vi kan have det køligt og regnfuldt i nogle dage, hvorefter vejret skifter til en varmere type, som vi så kan have i nogle dage. Disse skift har været afgørende for, at det danske landbrug har udviklet sig, som det har.

Men at have den samme vejrtype $\mathrm{i}$ flere måneder er usædvanligt - og så to år i træk med hver deres type. Vi ved endnu ikke, om det er en tendens, vil det blive svært for landbruget at vide, hvad man skal satse på af afgrøder. En kølig og våd vejrtype som i 2017 vil understøtte visse afgrøder, men 2018 vil kræve mere tørkeresistente afgrøder - og beslutningen om afgrøderne skal tages enten om efteråret eller i det tidlige forår.

\section{Naturbrandene}

En af de mange konsekvenser ved den tørre sommer var naturbrandene. De var massive og forekom mange steder i Europa. Det er logisk, at tørre år vil give større risiko for naturbrande, men selv om der ikke kan påvises en

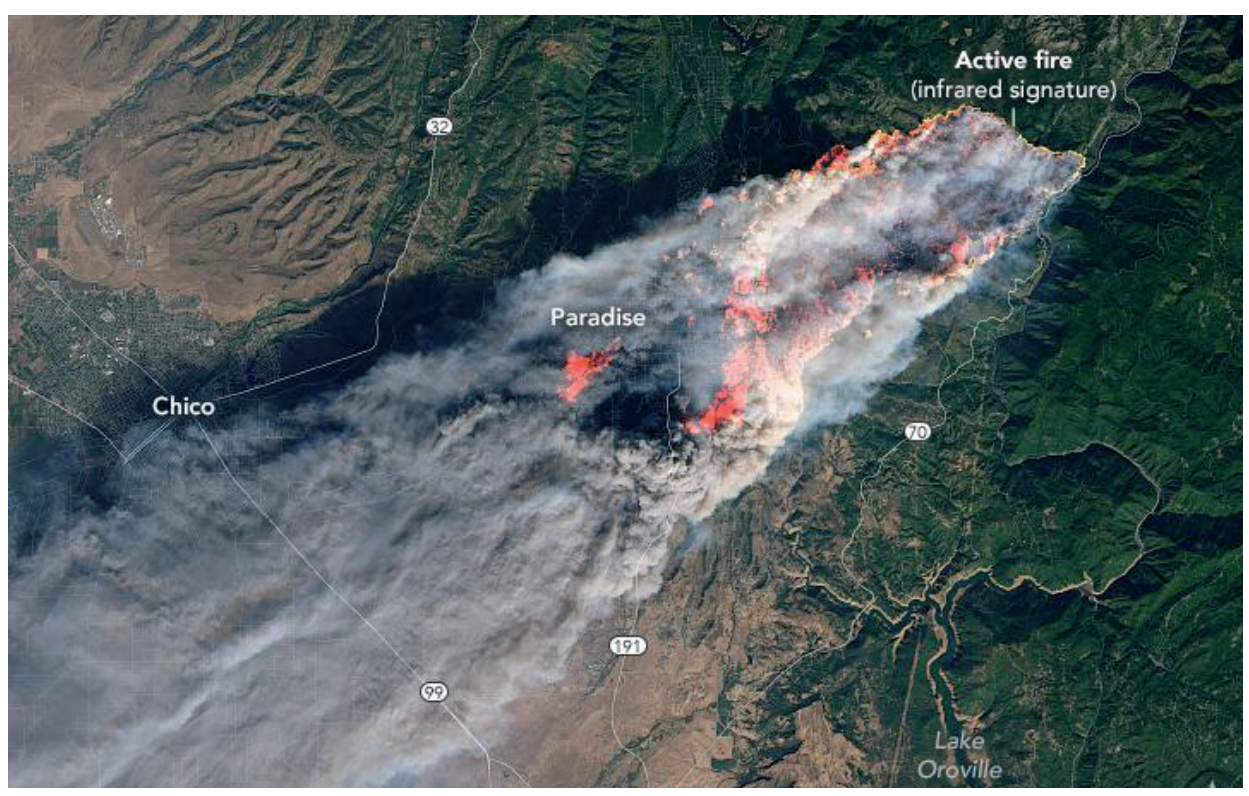

FOTO: NASA Earth Observtory 
Problemet med afsmeltningen i Arktis, i Grønland, på gletsjere og på Antarktis er både, at isens klimaregulerende faktor forsvinder, og at smeltevandet siver ud i havene, hvor havspejlet stiger. der frigivet meget store energimængder til skyen. Det medfører, at skyerne bliver mere energirige, så de vokser mere vertikalt og bliver derfor mere koncentrerede som bygeskyer. Vi kender det fra de varmere egne på kloden, hvor nedbøren netop er voldsom og intens og samtidig koncentreret på et mindre areal.

Det er grunden til, at vi har set flere kraftige skybrud herhjemme med over $100 \mathrm{~mm}$ regn på meget kort tid. Kommunerne har gennem de senere år udført klimatilpasning, så den voldsomme regn ikke medfører oversvømmelser i borgernes kældre men ledes andre steder hen. De mange infrastrukturelle indsatser er et eminent eksempel på den klimatilpasning, som er nødvendig for, at det varmere klima ikke skal skabe unødige ulykker.

Men som tidligere nævnt er det ikke kun i Danmark, vi ser netop disse forandringer. Globalt har vi været vidne til mange oversvømmelser, og det er i princippet samme fysik, der er baggrunden. Varmere hav vil give mere fordampning og dermed mere nedbør. Hele monsunsystemet i Sydøstasien ser ud til at være blevet mere ustabilt. Befolkningerne har hidtil haft en forventning om regntid og tørtid, men det har ændret sig.

Senest her i januar i år, hvor det normalt er tørtid, har en tropisk storm helt usædvanligt ramt nogle thailandske øer. Regnen, som falder i regntiden, er samtidig blevet mere intens og falder mere lokalt. Disse forhold spiller naturligvis ind i områ- 
dets økonomi på både landbrug- og turistindustrien.

\section{Isen som smelter}

Ser vi væk fra de direkte vejrmæssige konsekvenser af den højere temperatur, falder blikket i reglen på de kolde egne, hvor isen smelter. Heller ikke det er overaskende, men det fører til en forandring af den klimapåvirkning, som isen har. Den hvide overflade fra sneen reflekterer sollyset, så den energi ikke indgår i energiregnskabet, fordi det sendes tilbage i verdensrummet. Sollys er kortbølget elektromagnetisk stråling, der næsten uhindret passerer gennem atmosfæren, og en refleksion på en hvid overflade ændrer ikke på bølgelængden. Det er anderledes med jordoverfladens langbølgede udstråling. Den forhindres i et vist omfang af drivhusgasserne i atmosfærens, så en del energi tilbageholdes i jordatmosfæresystemet.

Men når sneen smelter, kommer den mørke overflade fra jorden eller vandet under sneen til syne. Den mørke overflade vil suge sollyset til sig og derfra få en opvarmning, der igen smelter mere is. Den form for såkaldt positive feedbackmekanismer er en farlig cocktail, da det i den sidste ende risikerer at øge afsmeltningen dramatisk. Problemet med afsmeltningen i Arktis, i Grønland, på gletsjere og på Antarktis er både, at isens klimaregulerende faktor forsvinder, og at smeltevandet siver ud i havene, hvor havspejlet stiger.

Det gør havet desuden også, når havtemperaturen stiger, idet et varmere hav simpelthen fylder mere. Samlet

\section{Vi har mulighederne for at sætte effektivt ind imod klimaændringerne. Spørgsmå- let er blot, om politikerne har det mod, der skal til.}

set vil de to effekter få havet til at stige ved vore kyster. Hvor stor stigningen bliver, er der naturligvis stor usikkerhed omkring, men et konservativt bud er mellem 30 og $60 \mathrm{~cm}$ i dette århundrede. Det vil øge presset på vore diger, som ikke er høje nok til at modstå den stigning. Under orkanen 3. december 1999 stod vandet helt oppe ved digekronen, og kun fordi det samtidig var astronomisk lavvande, løb vandet ikke over diget. Men hvis det var sket seks timer før eller efter, ville vandstanden have været op mod en meter højere, og katastrofen have været en realitet. Det skete ikke denne gang, men risikoen vil øges i takt med, at havet stiger, og stormene risikerer at blive stærkere. For den risiko ligger også i forskernes udmeldinger. Der kommer ikke nødvendigvis flere storme, men de kraftige vil blive endnu stærkere egentlig den samme forventning, som der også er til de tropiske orkaner.

\section{Internationalt perspektiv}

Set $i$ et mere internationalt perspektiv vil Danmark også blive påvirket af klimaændringer andre steder i verden. Dels kan der blive tale om økonomiske tilbageslag, og dels kan klimaændringer sætte gang i flygtningestrømme mod Europa, hvis levevilkårene i bl.a. Afrika forværres. For der er stadig områder, som er så udsatte, at selv små klimaændringer som tørke eller oversvømmel- 
ser kan vælte livsgrundlaget for mange mio. mennesker. Hvis verdenssamfundet ikke formår at hjælpe tilstrækkeligt her, vil mange menneske blive nødt til at søge andre steder hen.

Overordnet set er der mange trusler fra det foranderlige klima. I hvor høj grad de i den nære fremtid vil blive til reelle trusler, er mest et spørgsmål, hvorvidt om politikerne - nationalt og internationalt - vil være i stand til at samarbejde omkring de løsninger, som lige nu eksisterer, og de nye løsninger og teknologier, der vil blive udviklet.

Vi har mulighederne for at sætte effektivt ind imod klimaændringerne. Spørgsmålet er blot, om politikerne har det mod, der skal til. For selv om vi alle har et ansvar i vores daglige virke, er det nødvendigt med internationale aftaler for at løse klimakrisen på længere sigt.

Vi har mulighederne for at sætte effektivt ind imod klimaændringerne. Politikerne mødes hvert år til det årlige COP-møde, hvor det seneste var i Katowice i Polen i december. Det var det 24. i rækken, og der skete også gode ting på det møde. Der var især tre emner på den store dagsorden - Parisaftalens regler, Parisaftalens ambitionsniveau og Parisaftalens finansiering. For Parisaftalen står helt centralt i det klimatiske løsningskompleks.

Reglerne, der handler om, hvordan rapportering af klimagasser skal foregå, blev forhandlet på plads. Det var rigtig godt, for det er nødvendigt at kende procedurerne, når aftalen træder i kraft i 2020 .

Finansieringen faldt også stort set på plads. I al fald kom man et stort skridt nærmere en enighed om hvilke penge, der skal regnes med, når behovet for klimafinansieringen på 100 mia. USD hvert år skal leveres fra 2020.

Men det springende punkt var Parisaftalens ambitionsniveau. Alle ved, at de reduktionsmål, der er indeholdt i Parisaftalen, ikke er nok. De vil give en temperaturstigning på mellem $3,0 \mathrm{og}$ 3,5 grader. Så der skal mere til, og derfor var der stor forventning til rapporten fra FN's klimapanel - IPCC - om 1,5 graders målet. Rapporten, der kom i begyndelsen af oktober, var meget klar. Verden skal reducere udslippet af drivhusgasser med næsten 50 pct. i løbet af de næste 12 år. Men under COP24 skabte en alliance mellem USA, Rusland, Saudi-Arabien og Kuwait usikkerhed om, hvor meget rapporten skulle betyde. De fire lande ville ikke have, at IPCC's beregninger skulle indgå i COP24-beslutningen. Så det blev alene til, at landene kunne bruge rapporten, hvis de havde lyst. Det vil så $i$ år vise sig, i hvor høj grad, det bliver tilfældet.

I vores eget land har vi en opfattelse af, at vi er meget klimabevidste og grønne. Det stammer især fra Svend Aukens tid, hvor han italesatte behovet for en forandring af vores udnyttelse af naturen. Det var årene, hvor de grønne teknologier vandt frem og ikke mindst, hvor vindmølleeventyret udviklede sig.

Det image af Danmark har holdt ved, selv om vi på det seneste ikke har været interesseret $i$ at have den grønne førertrøje. Med lidt øget initiativ kan vi nok erobre den igen - hvis vi vil!

$0 \circ 0$ 